\title{
EFFECTS OF MENHADEN FISHING UPON THE SUPPLY OF MENHADEN AND OF THE FISHES THAT PREY UPON THEM
}

From BUILETIN OF THE BUREAU OF FISHERIES, Volume XXVIII, I9O8

Proceedings of the Fourth International Fishery Congress : Washington, I908

WASHINGTON : : : : : : GOVERNMENT PRINTING OFHICE : : : : : : 1910 


$$
\%
$$


. 



\section{EFFECTS OF MENHADEN FISHING UPON THE SUPPLY OF MENHADEN AND OF THE FISHES THAT PREY UPON THEM * * * * $*$}

From BULLETIN OF THE BUREAU OF FISHERIES, Volume XXVIII, Igo8

Proceedings of the Fourth International Fishery Congress : : Washington, Igo8

\footnotetext{

}

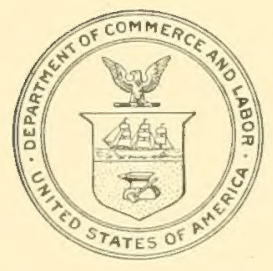

WASHINGTON : : : : : : GOVERNMENT PRINTING OFFICE : : : : : 1910 




BUREAU OF FISHERIES DOCUMENT NO. 657.

Issued February, 1910.

FEB 11.1910
D OR D 
EFFECTS OF MENHADEN FISHING UPON THE SUPPLY OF MENHADEN AND OF THE FISHES THAT PREY UPON THEM *

\author{
By Walter E. Hathaway
}

*

Paper presented before the Fourth International Fishery Congress

held at Washington, U. S. A., September 22 to 26, 1908 


\section{CONTENTS.}

$*$

Introductory _......

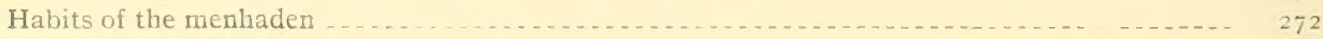

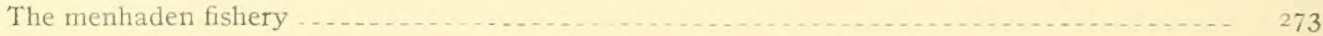

Effects of the fishery upon movements and numbers of menhaden $\ldots \ldots \ldots \ldots \ldots \ldots \ldots . .274$

Effects of the menhaden fishery upon predatory fishes

Conclusion _. 


\section{EFFECTS OF MENHADEN FISHING UPON THE SUPPLY OF MENHADEN AND OF THE FISHES THAT PREY UPON THEM.}

\section{*}

BY WAITER E. HATHAWAY.

\section{$*$}

The object of this essay is to determine impartially, as nearly as possible from the facts and information obtainable, the effects of fishing, with modern and improved apparatus, on surface-swimming fishes and on such fish as prey upon them. This inquiry, therefore, will naturally proceed from two standpoints: First, the effect directly on the surface-swimming fishes, and, second, the effect on such predatory fishes as feed upon those of the former class.

While it is the habit of nearly all of the migratory fishes that inhabit the waters of the middle and north Atlantic coasts of the United States during the spring, summer, and fall months of the year, such as bluefish, weakfish (which south of the Delaware Bay are known by the general name of "trout" and north and east of Montauk Point as "squeteague"), drum, bonito, mackerel, and menhaden, while on passage, to travel in schools and largely on or near the surface of the waters, these all, except the mackerel and the menhaden, disperse when reaching their feeding grounds and appear infrequently on the surface thereafter. While the mackerel is at times during the entire summer and fall a surface-swimming fish, and is also found in schools, it is more generally found in small and scattered numbers and often deep under the surface.

Therefore for the purpose of this inquiry the menhaden alone will be considered, as of all the fishes that inhabit these waters it alone, strictly speaking, is a surface-swimming fish, and invariably swims in schools. However, conditions of the weather, especially the temperature of the water, and the presence of enemies, whether man or fish, have great influence upon the actions of these fish. They have often been known to be in certain waters in great abundance for days, weeks, and even months, but in such scattered numbers that they could not be successfuily taken in purse nets, and at such times appearing on the surface only at intervals, longer or shorter, under the, most pleasant and favorable weather conditions.

No notice will here be taken of such fish as shad, herring, and alewives, which seek the shores only to spawn and not for feeding grounds. The principle governing the catching of them is entirely different from that of catching the menhaden, which come to the shores to feed and not to spawn. 
HABITS OF THE MENHADEN.

It is true that the menhaden do spawn on the Atlantic coast of the United States, but only in limited numbers. Spent fish have been found all along the coast from Maine to Florida, but never on their passage north. Such fish have been examined in Maine as early as July i 5 and on the Atlantic coast of Florida as late as December I 5. The small fish of that season's spawning are found all along the coast south of Sandy Hook, for the most part during the months of August and September. They have rarely been seen north and east of Long Island. During the first week in September, r9o6, the writer saw several schools of very small menhaden, from $\mathrm{I} / 2$ inches to 2 inches long, in the harbor of Vineyard Haven. Old fishermen, whose observation of those waters had extended over long periods, in one case fifty years, stated that they had never seen them there before.

It is unquestionably a fact, although up to this time not demonstrable from actual observation and investigation, that the menhaden spawns principally in the warm waters south of the United States, probably in the Caribbean Sea, and mainly during the months of January, February, and March. The writer examined many hundreds of menhaden caught from the 20 th of November to the roth of December, I 906 , between Cape Lookout and Georgetown, S. C., and without a single exception they were fish due to spawn in from thirty to sixty days; those fish were moving south at a rate of from 20 to 50 miles per day.

Menhaden are also found in large quantities and have been and are being taken for commercial purposes in the Gulf of Mexico, but these are slightly different in appearance and habits from the menhaden found in the Atlantic Ocean, being a little heavier in body in proportion to length and less active. It is believed that they do not migrate into the Atlantic, but remain about the Gulf coasts of the United States and Mexico.

Many different theories have been advanced and maintained as to the spawning habits of the menhaden and also as to their habitat during the winter and early spring months; but it is believed by the writer, from a very careful personal observation of these fish for the past twenty years and over the entire eastern coast of the United States from Maine to Florida, that the statements herein made are, as nearly as present knowledge of the subject will justify, correct and accurate. This statement, however, is made with due modesty; for upon one occasion when he asked an old fisherman who had taken menhaden for fifty years, and all the way from Casco Bay, in Maine, to Port Arthur, 'Tex., "Captain, what do you know about menhaden?" the answer, very emphatically given, was, "Not a damn thing."

It is, however, a clearly established fact that the menhaden seek this coast for food and not to spawn. 
The menhaden, scientifically known as Brevoortia tyramus, has many local names along the coast - in North Carolina, "fat backs;" in Virginia, "old wives;" in New Jersey and New York, "moss bunkers;" and generally in New England, "pogies."

As is common with all migratory fish, the oldest and strongest go farther afield, in the case of the menhaden farther north. Therefore the size of the fish found on various parts of the coast differs; the average size of the fish caught on the principal grounds heing, in Maine, ahout $\mathrm{I}_{2}$ inches; in I ong Island Sound and adjacent waters, about ro inches; on the "Jersey beach" and in Delaware Bay, about 9 inches; in Chesapeake Bay, about 8 inches, and south of Cape Hatteras, 6 to 7 inches.

On their journey north, which begins usually in March, the fish do not follow the coast, but travel some distance out at sea, the schools "striking in " near their usual feeding grounds. Returning, which, migration begins from New England waters early in September, those about and north of Cape Cod usually disappear first from Nantucket Shoals and the waters adjacent to No-MIan's Land. From Cape Cod to Sandy I Inok they sometimes follow the ocean side of Long Island and the New Jersey coast as far as Cape IIay, sometimes disappearing off Montauk Point. Those spending the summer on the "Jersey beach" and south of the Delaware usually follow the coast to Cape Hatteras and often even to the Savannah River. Therefore in the late fall and early winter large fish are often taken as far south as Charleston.

Having thus with reasonable certainty established the nature and habits of the menhaden, the next and most important part of our inquiry is, What effect has the taking of them by man had upon the supply and quantity, and also upon their movements?

\section{THE MENHADEN FISHERY.}

Menhaden have been taken along the Atlantic coast since the first settling of the country by white men. Indeed, it is believed that the Indians were acquainted with the use of fish to enrich the ground. Up to about is;o they were taken in small quantities only, in the smaller bays and inlets and in the mouths of the rivers, wenerally in shallow water, with very simple devices, and they were used mainly for fertilizer or manure, but in part for food. For many years they have been userl in a small way for food by the negroes and poorer whites along the southern coast country. Properly cleaned and salted they can be eaten with relish in default of a better fish. The fresh roe, fried, is not bad food and is sometimes caten in the coastal country south of Cape Hatteras, when the fish are taken on their way south in the months of November and December. The whole fish, either applied directly to the land or composted with barnyard manure or woods litter, has been used as a fertilizer all along the Atlantic coast of the United States since early colonial times. 
But this was a wasteful and ultimately injurious process if continuously applied, because the oil in the fish was not only lost but in time seriously damaged the soil, causing it to become stiff, gummy, and sour. The first commercial use of the oil was due to the ingenuity of a woman, about the year i85o. 'The process of cxtracting the oil was at first very crude, and the remainder of the fish, the "scrap," was for the most part thrown away. Both the oil and the "scrap" are now manipulated with improved and expensive machinery and apparatus.

At the present time there are about 30 factories with 70 steamers engaged in the business of taking menhaden and making them into "scrap" and oil. The average annual catch is about 600,000,000 fish, producing some 70,000 tons of "scrap" and 35,000 barrels of oil. The industry has been on its present basis since about i 885 . During these twenty-three years the annual catches have varied greatly, from about $250,000,000$ in 1892 to over $1,000,000,000$ in 1903 , but there has been little or no variance in the average for a period of years. The catch per steamer per season has also greatly varied, owing to locality of operations and the proverbial luck of fishermen, from 3,000,000 or $4,000,000$ to $23,000,000$. The season of 1906 was a poor one; last season, 1907, was poorer, the total catch not being over 350,000,000. This season up to the date of this writing, September 7 , has been one of the best ever known, and prospects are for a catch of at least $800,000,000$. 'These facts seem to demonstrate clearly that so far as abundance is concerned, taking an average period of years, there has been no diminution of the quantity. Weather conditions, particularly the temperature of the water, govern the movements of menhaden greatly. This has been an ideal season, the weather along the coast from Hatteras to Montauk having been uncommonly mild and pleasant; during the previous two seasons of 1906 and 1907 , on the contrary, these conditions were exceedingly unfavorable.

EFFECTS OF THE FISHERY UPON MOVEMENTS AND NUMBERS OF MENHADEN.

What effect has this fishing on the morements of the fish? Generally, the constant operation of modern seines and steamers at, in, and about the mouths of the narrower estuaries of the ocean have a tendency to keep the fish out of such waters. To illustrate, the daily operation during the early months of this season of some 30 steamers about the mouth of the Chesapeake Bay undoubtedly kept fish that had started for that water away, and turned them both up and down the adjacent parts of the Atlantic coast, and notwithstanding the general abundance of these fish this year they have been uncommonly scarce in the upper part of the Chesapeake Bay and the rivers emptying into it. The fishing on the present scale has kept the fish out of the smaller bays, inlets, and rivers in the immediate neighborhood of large seining operations in the near-by ocean. Also, excessive or reckless fishing, even when on very large schools, and especially when the fish are on their migratory move- 
ments, will often cause them to scatter, become wild, and even disappear altogether.

To sum up, the annual taking of some $600,000,000$ of menhaden per season for the past twenty-three years has to no perceptible extent or in any perceivable amount diminished the average number in the ocean and its great estuaries; but it has lessened the quantity in some of the smaller water areas adjacent to large fishing operations, in some cases almost to extinction. The self-evident lesson to be learned hy the connercial menhaden fishermen-and the nature of this fish is such that no one else has even a remote interest in it is that in the future these fish will be largely taken in the ocean with larger and faster steamers and more improved appliances.

EFFECTS OF THE MENHADEN FISHERY UPON PREDATORY FISHES.

There have been no menhaden, only a few excepted, north of Cape Cod since I 898. This is due in part, no doubt, to the increased destructiveness, in those waters, of dogfish, but scientists believe it to be due principally to the temperature of the water. Even the large and vigorous menhaden do not go to or remain in water cooler than $60^{\circ}$. It has been contended that these northern fish were all caught up by the steamers. Even were this true, for the last season in which there was any menhaden fishing in Maine, I898, why have they not returned? There have been comparatively no menhaden taken north of Cape Cod for ten years, and they have been abundant south of the Cape several years since $\mathrm{I} 898$, notably in 1903 , when over $\mathrm{I}, 000,000,000$ were taken.

It is distinctly the opinion of this writer, following the dictum of Colonel McDonald, that no migratory fish can be materially diminished, much less destroyed, by any appliances that the brain and ingenuity of man have yet devised, when not taken on their regular spawning srounds. The herring and mackerel fisheries, both in this country and in Europe, satisfactorily demonstrate this truth.

Lastly, let us consider what effect the taking of menhaden by man has on the fish that prey upon it. Nature's evident purpose in producing the menhaden was to supply food directly to fishes, and indirectly to man on account of its value for fertilizing purposes. It is, perhaps, the most promiscuously prolific of all fishes.

Almost all predaceous fish prey upon menhaden. In the order of their destructiveness, estimating the entire Atlantic coast of the United States, I would name the sliark, the blutish, the dogfish, the weakfish or squeteague, the porpoise, and the honito. "Ihe shark is their principal enemy' south of the Chesapeake. The writer opened one shark taken of the mouth of the Cape Fear River, in North Carolina, and actually counted 352 well-defined menhaden taken from its stomach, at least half of them entirely whole; and he has seen thousands of them preying on schools of menhaten in the same waters. Many 
sharks are caught in the menhaden nets, as many as 275 having been taken by one steamer in one day. In the beginning of the menhaden fishery at the mouth of Delaware Bay sharks were very numerous in those waters, much more so than they are now, and it is believed that the constant taking of them in menhaden nets has caused this decrease. There can be no doubt that whenever any fish that produces its young in such small numbers can be taken in any given water in large quantities its practical extinction is only a matter of persistence and reasonable time; and the writer, who has seen 7 tons of dogfish taken at one lifting of a deep-sea trawl, in experiments conducted by The Fisheries Company to the south of Block Island in September, 1907, is entirely satisfied that that pest of the North Atlantic coast can practically be exterminated.

The bluefish is so erratic in its nature and habits and of such uncertain and irregular labitat that little can be said about it with any positiveness. It unquestional, ly eats and destroys large quantities of menladen, especially north of Delaware Bay, but as it is never caught in quantities in seines, and feeds on all other varieties of fish smaller than itself, it is not believed by the best authorities that the taking of menhaden by man has any effect whatever on bluefish.

The only food fish of any particular value, other than the bluefish, that feeds to any extent on the menhaden is the weakfish, or squeteague. There is quite an extensively entertained opinion in certain places along the coast, especially in New Jersey and southern Massachusetts, that the constant taking of menhaden by the steamers materially diminishes the quantity of weakfish and squeteague for the anglers-for the reason that the food being taken the weakfish and squeteanue seek other waters more profitably supplied. If these people would only just for a moment realize that only the largest weakfish feed on menhaden, those under 3 pounds rarely ever eating any but very small menhaden, and that the larse weaklish is a sea lish and seldom frequents the small bays and inlets, they would know how silly this belief is. It is a fact that the catch of weakfish in the pounds on the New Jersey coast and by the New Jork fishing smacks has increased year by year, notwithstanding the large numbers of menhaden annually taken from the same waters. It can be asserted witl entire confidence that the taking of menladen by man has had absolutely no effect on the abundance or movements of weakfish during the existence of the menhaden industry.

G. Brown Goode, in his "History of the American Menhaden," says:

Is it too much, then, to multiply the three hundred millions of millions of menhaden probably consuned by the full-grown bluefish alone on the coast of New England in the summer months by ten? This would allow three thousand millions of millions of menhaden, old and young, annually destroyed in the waters of the United States, in comparison with which the number annually taken by men is perfectly insignificant. This estimate will seem extravagant at first sight, but I believe that it will be found a very moderate one by any who may take the pains to investigate the question for themselves. 
This opinion has been approved and concurred in by Professor Baird, Colonel McDonald, and Dr. I I gsh M. Smith, than whom there are no higher authorities on the subject to be found. Assuming that it is even approximately correct, can any intelligent person, even with the rreatest stretel of faney, imagine that the comparatively few menhaden taken by man can in any way affect the fish that prey on the menhaden, which have for thousands of years been taking thousands of menhaden for every one that man has taken during a few years?

\section{CONCLUSION.}

There can be no question but that the fishing by man has in no way diminished the quantity of menhaden in the ocean, the only effect having been to retard or change the movements of small lots, in and about specially located bodies of water. Nor has it had the minutest effect on the preclaceous fish that feed upon them, except the possible decreasing of slarks in the waters north of Cape Charles, and this may be clue to other causes than taking then in nets with menhaden. Extensive investigations made under the authority of Dr. Ingh M. Smith, of the United States Bureau of Fisheries, have clearly demonstrated the fact that food fish are seldom taken in the menhaden nets and never in any quantities. The writer, first and last, has seen perhaps I00,000,000 menhaden taken, among all of which there were not $\mathrm{I}, \mathrm{ooo}$ food fish of any kind.

When we consider the illimitable vastness of the ocean's extent; the marvelous fecundity of the menhaden, one female producing sometimes 18 , ono egrs; the incalculable numbers there must be in all the waters, as many as 500,00o having been taken from a space of less than an acre's surface; we can inevitably reach but one conclusion: 'That they were designed in the all wise provisions of nature for man's use and benefit, and it belooves man, with such skill as his wisdom and ingenuity can devise, to take them and use them, believing that for every one he can take each rear probably tens of thousands die and are destroyed by other agencies.

\section{DISCUSSION.}

The PRESIDENT. The menhaden always provokes discussion. I know the Bureau of Fisheries has for twenty years been making observations at IVoods Hole on the breeding habits in the neighborhood of Buzzards Bay and Vineyard Sound. I dare say that Doctor Smith will give information in regard to the results of the observations made upon the breeding habits of the menhaden in the north.

Dr. Hugn M. Surtr (secretary-general). Mr. President and ladies and gentlemen, I do not intend to discuss the menhaden question, but there is just one point brought up by the last speaker to which I would invite attention. Mr. Hathaway is undoubtedly in error in regard to the spawning of the menhaden. The spawning habits of this fish are now pretty well known, thanks to the efforts of the United States Bureau of Fish- 
cries and several of the States on the middle Atlantic coast. There appears to be a double spawning period, quite similar to that of the sea herring on the Atlantic coast of the United States. In spring and early summer the menhaden spawns in abundance on the middle Atlantic coast-northern part of the middle Atlantic and southern part of the New England coast; and in late autumn and early winter the menhaden spawns in great abundance on the southern part of the middle Atlantic coast and the northern part of the south Atlantic coast. Ripe eggs from both of these regions have frequently been examined.

Mr. Alexander COOPER (Delaware). I have but a few words to say. The importance of an international congress to consider the foreign and domestic fisheries of the United States is universally conceded. The time has come when something must be done to preserve the food fish, which are rapidly disappearing from American waters. I speak partictlarly of the shad and sturgeon fishing along the Atlantic coast, and still more particularly of that great industry as it exists in the Delaware bay and river. The most direct cause of this depletion with us consists in the pollution and contamination of the waters in which these fish live and propagate their species by the owners of oil refineries, factories, and mills permitting their poisonous and refuse matter to flow into the water, thereby practically destroying the spawning grounds or so affecting them as to drive the fish to other localities. There are other causes for this depletion of these fish, which seem to be pretty well known. One of them may be stated in connection with Mr. Hathaway's paper. I have had the pleasure of meeting Mr. Hathaway before. About two years ago I was appointed one of a commission of three from the state of Delaware, to meet with a like commission from the state of New Jersey, to consider a compact which had been entered into between these two states and which has since been ratified by Congress, and to draft uniform fishing laws for the two states, regulating their respective fishing rights in the Delaware bay and river. A serious question presented itself to us in regard to the menhaden fisheries-whether the men engaged in these fisheries caught food fish, and particularly shad. Mr. Hathaway appeared before us and urged that they did not catch any food fish worthy of mention. The shad and shore fishermen contended on the other side that they did - that the shad passed out into the ocean in large schools, particularly in the month of September, swimming on the surface of the water like the menhaden, and were caught like the menhaden, and used as such.

I do not present this matter in a controversial way, but suggestive only, so that the matter can be investigated and, if true, remedied in some way. It has long been an important question to the shad fishermen of the Delaware River.

Mr. GEORGE P. Souines. I heard Mr. Hathaway, who is my neighbor; I have also heard this kind gentlemen. I am no lawyer. I am simply a fisherman of fifty years' hard labor. I have this to say to this gentleman and to everyone of this congress. I do it upon the authority of my governor, and do it with pleasure. I do it with the authority of our Association of Menhaden Fishermen of the Chesapeake Bay.

Just as this kind gentleman has stated, the great object is to save the food fish. I, as the president of our association, am authorized to say to gentlemen who are here, foreign or of our own country, that we will welcome them to come among us. We will place one of our steamers at their disposal-any man or men; we will treat you as Old Virginia can treat you. Come, and see for yourselves. Talse our crews and work them by yourselves. Come, gentlemen, and see how much the menhaden fishery is a benefit to the future of the fish of our country. Come on! 



